\title{
Assessment of Suitability of Fallow Lands for Major Medicinal Plants in Tamil Nadu
}

\author{
S. Dharumarajan ${ }^{1 *}$, L. G. K. Naidu ${ }^{1}$, M. Lalitha ${ }^{1}$, R. Vasundhara ${ }^{1}$, K. S. Anil Kumar ${ }^{1}$, Rajendra Hegde ${ }^{1}$ and S. K. Singh ${ }^{2}$ \\ ${ }^{1}$ National Bureau of Soil Survey and Land Use Planning, Regional Centre, Hebbal, Bangalore, Karnataka (560 024), India \\ ${ }^{2}$ National Bureau of Soil Survey and Land Use Planning, Amravati Road, Nagpur, Maharashtra (440 033), India
}

\begin{tabular}{l}
\hline \hline Article History \\
\hline \hline Manuscript No. AR1597 \\
Received in $14^{\text {th }}$ May, 2016 \\
Received in revised form $24^{\text {th }}$ June, 2016 \\
Accepted in final form $6^{\text {th }}$ August, 2016 \\
Correspondence to
\end{tabular}

"E-mail: sdharmag@gmail.com

\section{Keywords}

Fallow land, soil, medicinal plants, land suitability

\begin{abstract}
The present study was carried out to assess the extent of permanent fallow lands and identify the suitability of fallow lands for cultivation of major medicinal plants viz., Aswagandha (Withania somnifera Dunal), Senna (Cassia angustifolia M. Vahl) and Tulsi (Ocimum sanctum Linn) in Nanguneri Block of Tamil Nadu during 2013-14. Indian Remote sensing satellite Resourcesat-2 LISS IV data was used to map the extent and distribution of permanent fallow lands of study area and the detailed soil survey work was carried out to identify the problems and potentials of land resources. The biophysical survey revealed that $41.3 \%$ of total geographical area (TGA) in Nanguneri block is identified as permanent fallow lands. Climate and soil resources of fallow lands were evaluated for the medicinal plants suitability for cultivation using the parametric methodology. The results showed that out of 5 identified soils, two soils $\left(\mathrm{N}_{4}\right.$ and $\left.\mathrm{N}_{5}\right)$ are highly suitable for cultivation of all the three medicinal plants. Depth, soil texture and soil $\mathrm{pH}$ are identified as a major constraints in other soils. The area analysis revealed that $53.4 \%$ of fallow lands in Nanguneri block are highly suitable for Aswagandha and $72.2 \%$ of fallow lands as highly suitable for Senna and Tulsi cultivation. These results can be transferred to the local stakeholders for converting unproductive fallow lands into productive hub for medicinal plants.
\end{abstract}

\section{Introduction}

Indian sub-continent is blessed with most diverse soil and climatic conditions, which are suitable for the growth of many medicinal plant species. Medicinal and aromatic plants and their products to the tune of ₹ 200 crores are produced annually in the country and also India exports large quantities of medicinal and aromatic plants and derivatives to various countries (Rajendran et al., 2008). There is a considerable scope for India to contribute towards the increasing worldwide demand for medicinal plant products (GOI, 2000). Since the major prime lands of country are occupied with cereals and cash crops, medicinal plants are allocated to marginal and degraded lands which resulted to low productivity. Identification and allocation of suitable land for medicinal plants cultivation is a challenging task for stakeholders (Pirbalouti, 2009, Pirbalouti et al., 2011; Nimasow et al., 2016).

On the other hand, large extent of productive lands are left as fallow for more than year due to uneconomical returns from agriculture, inadequate supply of water, severe soil constraints, silting of canals and rivers, soil and water pollution and socio-economic conditions of farmers (Sharma et al., 2011; Natarajan et al., 2010; Ramasamy et al., 2005). The Govt of India statistics showed that permanent fallow lands in India are increased from $8.8 \mathrm{mha}$ in $1970-71$ to $10.3 \mathrm{mha}$ in $2010-11$ (DES, 2013). Permanent fallow lands in Tamil Nadu state has increased drastically from 0.61 mha in 1960's to $1.1 \mathrm{mha}$ in 1990 's and to 1.54 mha in 2009-2010 which is $11.4 \%$ of the total geographical area of the state (Season and Crop report of Tamil Nadu, 2011).

The untapped potential of the fallow lands if harnessed and allotted to high value crops such as medicinal plans it would enhance production and provide greater benefits to the poor and marginal farmers of the region. In this context, the present paper aims to bring out suitability of permanent fallow lands for cultivation of major medicinal plants. Three medicinal plants Aswagandha (Withania somnifera Dunal), Senna (Cassia angustifolia M. Vahl) and Tulsi (Ocimum sanctum Linn) were selected and evaluated for suitability for fallow lands of Nanguneri block. Aswagandha roots and its leaf and seed are 
used in ayurvedic and unani medicines. Roots are prescribed in medicines for hiccup, several female disorders, bronchitis, rheumatism, dropsy, stomach and lung inflammation and skin diseases (Shah et al., 2010; Khanna et al., 2006; Kulkarni and Dhir, 2008). Aswagandha is late kharif crop and grows well under dry climate. It grows well in well drained sandy loams or light red soils, having $\mathrm{pH}$ of 7.5 to 8.0 and requires 600 to $750 \mathrm{~mm}$ rainfall for successful cultivation of Aswagandha (Jat et al., 2015; Ramamurthy and Singh, 2015; Naidu et al., 2006). The soil site suitability criteria ratings for Aswagandha are given in Table 1.

Senna botanically known as Cassia angustifolia M. Vahl leaves and the pods are the economical parts, containing sennosides which have laxative properties. It was considered as a "cleansing" herb because of its cathartic effect (Kayina and Reddy; 2012, Ramamurthy and Singh, 2015). It is mainly used as a purgative. Soil site suitability criteria ratings for Senna are given in Table 2. Tulsi or Ocimum sanctum Linn, the most sacred herbs in Ayurveda and considered good for the lungs and strengthens the adrenals (Cohen, 2014). Tulsi grows well in rich loamy soil with sufficient precipitation (Ramamurthy and Singh, 2015) and its suitability criteria ratings are listed in Table 3 . In the present investigation an attempt has been made to characterize the fallow lands of Nanguneri block and identify the best soils for cultivation of medicinal plants.

\section{Materials and Methods}

\subsection{Location of study}

Nanguneri block: It is located in Thirunelveli district with a total geographical area of 50,259 ha and lies between $77^{\circ} 51^{\prime} 42^{\prime \prime}$ ' and $77^{\circ} 35^{\prime} 55^{\prime \prime}$ East longitudes and $8^{\circ} 21^{\prime} 42^{\prime \prime}$ 'and $8^{\circ} 37>10$ »> North latitudes (Figure1). The elevation of the block ranged from $35-100 \mathrm{~m}$ above msl. The mean maximum temperature is $35.3^{\circ} \mathrm{C}$ and minimum temperature is $22.7^{\circ} \mathrm{C}$. The mean annual rainfall is $660.5 \mathrm{~mm}$ (Table 4). The LGP of Nanguneri block is 13 weeks which starts from September last week to end of December.

\subsection{Delineation of Fallow lands and characterisation}

Three seasons Resources at-2 Linear Imaging Self-Scanner (LISS IV) imagery of 2011-2013 was used for identification of fallow lands. Fallow lands were delineated by visual

\begin{tabular}{|c|c|c|c|c|c|c|}
\hline \multirow{2}{*}{$\begin{array}{l}\text { Land use requirement } \\
\text { Soil-site characteristics }\end{array}$} & & & \multicolumn{4}{|c|}{ Rating } \\
\hline & & Unit & $\begin{array}{c}\text { Highly suitable } \\
\mathrm{S}_{1}\end{array}$ & $\begin{array}{l}\text { Moderately } \\
\text { suitable } \mathrm{S}_{2}\end{array}$ & $\begin{array}{l}\text { Marginally } \\
\text { suitable } \mathrm{S}_{3}\end{array}$ & $\begin{array}{c}\text { Not } \\
\text { suitable N }\end{array}$ \\
\hline \multirow[t]{3}{*}{ Climatic regime } & Mean temperature in & ${ }^{\circ} \mathrm{C}$ & $28-32$ & $33-36$ & $36-40$ & $<10$ \\
\hline & growing season & & & $25-27$ & $10-24$ & $>40$ \\
\hline & Total rainfall & $\mathrm{mm}$ & $600-750$ & $500-600$ & $400-500$ & $<350$ \\
\hline \multicolumn{7}{|l|}{ Land quality } \\
\hline Moisture availability & $\begin{array}{l}\text { Length of growing } \\
\text { period }\end{array}$ & Days & $>150$ & $120-150$ & $90-120$ & $<90$ \\
\hline Oxygen availability to roots & Soil drainage & Class & Well drained & Moderate & Imperfect & Poor \\
\hline \multirow[t]{5}{*}{ Nutrient availability } & Texture & Class & sl, l, cl, sil, scl & $\begin{array}{l}\text { sicl, sic, sc, c } \\
\quad\left(\mathrm{m} \mathrm{k}^{-1}\right)\end{array}$ & $\mathrm{C}(\mathrm{ss})$ & ls, s \\
\hline & $\mathrm{pH}$ & $1: 2.5$ & $6-8$ & $5.0-5.9$ & $<5$ & \\
\hline & & & & $8.1-8.5$ & $>8.5$ & \\
\hline & CEC & $\begin{array}{c}\mathrm{C} \mathrm{mol} \\
(\mathrm{P}+) \mathrm{kg}^{-1}\end{array}$ & $>15$ & $10-15$ & $<10$ & \\
\hline & $\mathrm{CaCO}_{3}$ in root zone & $\%$ & $\begin{array}{c}\text { Non- } \\
\text { calcareous }\end{array}$ & $\begin{array}{l}\text { Slightly } \\
\text { calcareous }\end{array}$ & $\begin{array}{l}\text { Strong } \\
\text { calcareous }\end{array}$ & \\
\hline \multirow[t]{2}{*}{ Rooting conditions } & Effective soil depth & $\mathrm{cm}$ & $>75$ & $50-75$ & $25-50$ & $<25$ \\
\hline & Coarse fragments & Vol \% & $<15$ & $15-35$ & $>35$ & \\
\hline \multirow[t]{2}{*}{ Soil toxicity } & $\begin{array}{l}\text { Salinity (EC saturation } \\
\text { extract) }\end{array}$ & $\mathrm{dSm}^{-1}$ & Non-saline & Slight & Strongly & \\
\hline & Sodicity (ESP) & $\%$ & Non-sodic & Slight & Strongly & \\
\hline Erosion hazard & Slope & $\%$ & $<3$ & $3-8$ & $8-15$ & $>15$ \\
\hline
\end{tabular}




\begin{tabular}{|c|c|c|c|c|c|c|}
\hline \multirow{2}{*}{$\begin{array}{l}\text { Land use requirement } \\
\text { Soil-site characteristics }\end{array}$} & & & \multicolumn{4}{|c|}{ Rating } \\
\hline & & Unit & $\begin{array}{c}\text { Highly suitable } \\
\mathrm{S}_{1}\end{array}$ & $\begin{array}{l}\text { Moderately } \\
\text { suitable } \mathrm{S}_{2}\end{array}$ & $\begin{array}{l}\text { Marginally } \\
\text { suitable } \mathrm{S}_{3}\end{array}$ & $\begin{array}{c}\text { Not } \\
\text { suitable N }\end{array}$ \\
\hline \multirow[t]{2}{*}{ Climatic regime } & $\begin{array}{l}\text { Mean temperature in } \\
\text { growing season }\end{array}$ & ${ }^{\circ} \mathrm{C}$ & $26-32$ & $\begin{array}{l}24-25 \\
32-36\end{array}$ & $\begin{array}{l}15-23 \\
36-42\end{array}$ & $\begin{array}{l}<15 \\
>42\end{array}$ \\
\hline & Total rainfall & $\mathrm{mm}$ & $600-750$ & $500-600$ & $400-500$ & $<350$ \\
\hline \multicolumn{7}{|l|}{ Land quality } \\
\hline Moisture availability & $\begin{array}{l}\text { Length of growing } \\
\text { period }\end{array}$ & Days & $>150$ & $120-150$ & $90-120$ & $<90$ \\
\hline Oxygen availability to roots & Soil drainage & Class & Well drained & Moderate & Imperfect & Poor \\
\hline \multirow[t]{4}{*}{ Nutrient availability } & Texture & Class & sl, l, cl, scl, sil & sc, sicl, sic & $\mathrm{C}\left(\mathrm{m} \mathrm{k}^{-1}\right)$ & ls, c (ss), s \\
\hline & $\mathrm{pH}$ & $1: 2.5$ & $6.5-7.5$ & $\begin{array}{l}7.6-8.5 \\
5.0-6.4\end{array}$ & $\begin{array}{c}<5 \\
>8.5\end{array}$ & \\
\hline & CEC & $\begin{array}{c}\mathrm{C} \mathrm{mol} \\
(\mathrm{P}+) \mathrm{kg}^{-1}\end{array}$ & $>15$ & $10-15$ & $<10$ & \\
\hline & $\mathrm{CaCO}_{3}$ in root zone & $\%$ & $>8.5$ & $\begin{array}{l}\text { Slightly } \\
\text { calcareous }\end{array}$ & $\begin{array}{l}\text { Strong } \\
\text { calcareous }\end{array}$ & \\
\hline \multirow[t]{3}{*}{ Rooting conditions } & Effective soil depth & $\mathrm{cm}$ & $>75$ & $50-75$ & $25-50$ & $<25$ \\
\hline & Stonnines & $\%$ & & & & \\
\hline & Coarse fragments & Vol \% & $<15$ & $1-35$ & $>35$ & \\
\hline \multirow[t]{2}{*}{ Soil toxicity } & $\begin{array}{l}\text { Salinity (EC saturation } \\
\text { extract) }\end{array}$ & $\mathrm{dSm}^{-1}$ & Non-saline & Slight & Strongly & \\
\hline & Sodicity (ESP) & $\%$ & Non-sodic & Slight & Strongly & \\
\hline Erosion hazard & Slope & $\%$ & $1-5$ & $5-10$ & $10-15$ & $>15$ \\
\hline
\end{tabular}

interpretation. Forest survey of India maps (FSI, 2011), Topo sheets and soil map of Tamil Nadu (Natarajan et al., 1997) were used as reference information. Two year data sets were used to eliminate current fallows from permanent fallows. Ground truthing and detailed soil survey work was carried out during November-December, 2013.

\subsection{Field investigations and laboratory characterization}

The satellite imageries were visually interpreted based on textural and tonal variations and different land form units were delineated. Pre field landform map was verified in the field during 2013-14. Soil profiles were opened based on slope and landform characteristics and the soil and site characteristics were recorded for all profile sites as per the standard guidelines (Soil Survey Staff, 1993). Based on the soil-site characteristics, the profiles were grouped into different soil types and their area was delineated. Soil samples from representative profiles were collected and air dried and processed for laboratory analysis. Organic carbon was estimated by Walkley and Black (1934) method. The soil reaction (1:2.5 soil water suspensions), electrical conductivity and caution exchange capacity were determined by standard procedures (Jackson, 1973). Available Nitrogen (Subbiah and Asija, 1956), available Phosphorous by Olsen method (Olsen et al., 1954), available potassium by Neutral Normal Ammonium acetate method and micronutrients by DTPA method (Lindsay and Norvell, 1978) estimated to assess the status of fertility in the fallow lands. Soil attribute data collected from field and laboratory results were entered in ArcGIS platform for soil site suitability evaluation.

\subsection{Land suitability analysis}

The soil site suitability for medicinal plants has been evaluated as per the FAO frame work on land evaluation (FAO, 1983) modified by Naidu et al. (2006). The specific requirements of each medicinal plant compared with the characteristics of land and based on the extent of matching, the suitability of the area for the crop is arrived (Sys et al., 1991). Soil characteristics like depth, texture, gravelliness, $\mathrm{pH}$ and calcareousness, land features like slope, erosion and drainage and climatic factors such as amount of rainfall and its distribution and length of growing period was used to assess the suitability of land for different crops (Dharumarajan and Singh, 2014). 


\begin{tabular}{|c|c|c|c|c|c|c|}
\hline \multirow{2}{*}{$\begin{array}{l}\text { Land use requirement } \\
\text { Soil-site characteristics }\end{array}$} & & & \multicolumn{4}{|c|}{ Rating } \\
\hline & & Unit & $\begin{array}{c}\text { Highly suitable } \\
\mathrm{S}_{1} \\
\end{array}$ & $\begin{array}{l}\text { Moderately } \\
\text { suitable } \mathrm{S}_{2}\end{array}$ & $\begin{array}{l}\text { Marginally } \\
\text { suitable } \mathrm{S}_{3}\end{array}$ & $\begin{array}{c}\text { Not } \\
\text { suitable N }\end{array}$ \\
\hline \multirow[t]{4}{*}{ Climatic regime } & Mean temperature in & ${ }^{\circ} \mathrm{C}$ & $26-30$ & $24-25$ & $15-23$ & $<15$ \\
\hline & growing season & & & $31-34$ & $35-36$ & $>36$ \\
\hline & Total rainfall & $\mathrm{mm}$ & $600-1000$ & $500-600$ & $400-500$ & $<350$ \\
\hline & & & & $1000-1500$ & $1500-2000$ & $>2000$ \\
\hline \multicolumn{7}{|l|}{ Land quality } \\
\hline Moisture availability & $\begin{array}{l}\text { Length of growing } \\
\text { period }\end{array}$ & Days & $>150$ & $120-150$ & $90-120$ & $<90$ \\
\hline Oxygen availability to roots & Soil drainage & Class & Well drained & Moderate & Imperfect & Poor \\
\hline \multirow[t]{5}{*}{ Nutrient availability } & Texture & Class & sl, l, cl, scl, sil & sc, sicl, sic, s & $\mathrm{C}\left(\mathrm{m} \mathrm{k}^{-1}\right)$ & ls, c(ss) \\
\hline & $\mathrm{pH}$ & $1: 2.5$ & $6.5-7.5$ & $7.6-8.5$ & $<5$ & \\
\hline & & & & $5.0-6.4$ & $>8.5$ & \\
\hline & CEC & $\begin{array}{c}\mathrm{C} \mathrm{mol} \\
(\mathrm{P}+) \mathrm{kg}^{-1}\end{array}$ & $>15$ & $10-15$ & $<10$ & \\
\hline & $\mathrm{CaCO}_{3}$ in root zone & $\%$ & Non-calcareous & $\begin{array}{l}\text { Slightly } \\
\text { calcareous }\end{array}$ & $\begin{array}{l}\text { Strong } \\
\text { calcareous }\end{array}$ & \\
\hline \multirow[t]{3}{*}{ Rooting conditions } & Effective soil depth & $\mathrm{cm}$ & $>75$ & $50-75$ & $25-50$ & $<25$ \\
\hline & Stonnines & $\%$ & & & & \\
\hline & Coarse fragments & Vol \% & $<15$ & $15-35$ & $>35$ & \\
\hline \multirow[t]{2}{*}{ Soil toxicity } & $\begin{array}{l}\text { Salinity (EC saturation } \\
\text { extract) }\end{array}$ & $\mathrm{dSm}^{-1}$ & Non-saline & Slight & Strongly & \\
\hline & Sodicity (ESP) & $\%$ & Non-sodic & Slight & Strongly & \\
\hline Erosion hazard & Slope & $\%$ & $1-5$ & $5-10$ & $10-15$ & $>15$ \\
\hline
\end{tabular}

\section{Results and Discussion}

\subsection{Fallow lands delineation and characterisation}

The high resolution remote sensing data (Resoursat-2 IRS LISS IV) was visually interpreted and fallow lands were delineated and verified in the field. The results showed that $41.3 \%(20,770$ ha) of total geographical area are identified as permanent fallow lands in Nanguneri block. Low water availability, severe soil erosion, silting of canals and poor soil fertility, labour scarcity, inadequate capital and low profitability in agriculture are the major biophysical and socio-economical causes (Natarajan et al., 2010; Ramasamy et al., 2005) for increasing fallow lands in Nanguneri block.

Three distinct landform units were identified in the fallow land of Nanguneri block viz., nearly level summits and upland, gently sloping lands and concave slope lowland. Soil profile study was carried out across the landforms and the profiles were grouped into major soils based on differentiating characteristics (Natarajan and Sarkar, 2010). The major differentiating characteristics are depth, colour, gravels and texture. Five soils (soil $\mathrm{N}_{1}$ to Soil $\mathrm{N}_{5}$ ) were identified based on differentiating characteristics in the fallow lands of Nanguneri block. Soil morphological and physio-chemical properties of identified soils are presented in Table 5. The major soils in gently sloping uplands and summits are very shallow $(<25 \mathrm{~cm})$ red gravelly sandy clay soils $\left(\mathrm{N}_{1}\right)$, moderately shallow $(50-75 \mathrm{~cm})$ red gravelly clayey soils $\left(\mathrm{N}_{2}\right)$, moderately shallow $(50-75 \mathrm{~cm})$ black gravelly clayey soils $\left(\mathrm{N}_{3}\right)$ and moderately deep $(75-100$ $\mathrm{cm})$ gravelly sandy clay soils $\left(\mathrm{N}_{4}\right)$ whereas deep $(100-150 \mathrm{~cm})$ non gravelly sandy clay soils $\left(\mathrm{N}_{5}\right)$ observed in concave slope lowlands. $\mathrm{N}_{4}$ soils occupying largest area (7933 ha) followed by $\mathrm{N}_{3}$ (3932 ha) and $\mathrm{N}_{2}$ soils (3887 ha). $\mathrm{N}_{1}$ soils occupying lowest area (1814 ha) and deep non gravelly sandy clay soils $\left(\mathrm{N}_{5}\right)$ occupies $15.7 \%$ of total fallow lands.

Biophysical survey revealed that Soil $\mathrm{N}_{1}, \mathrm{~N}_{2}$ and $\mathrm{N}_{3}$ are having depth less than $75 \mathrm{~cm}$ which limits suitability for majority of deep rooted crops. Except soil $\mathrm{N}_{5}$, all the soils in Nanguneri block have moderate to severe problem of gravelliness. Soil $\mathrm{N}_{1}$ 


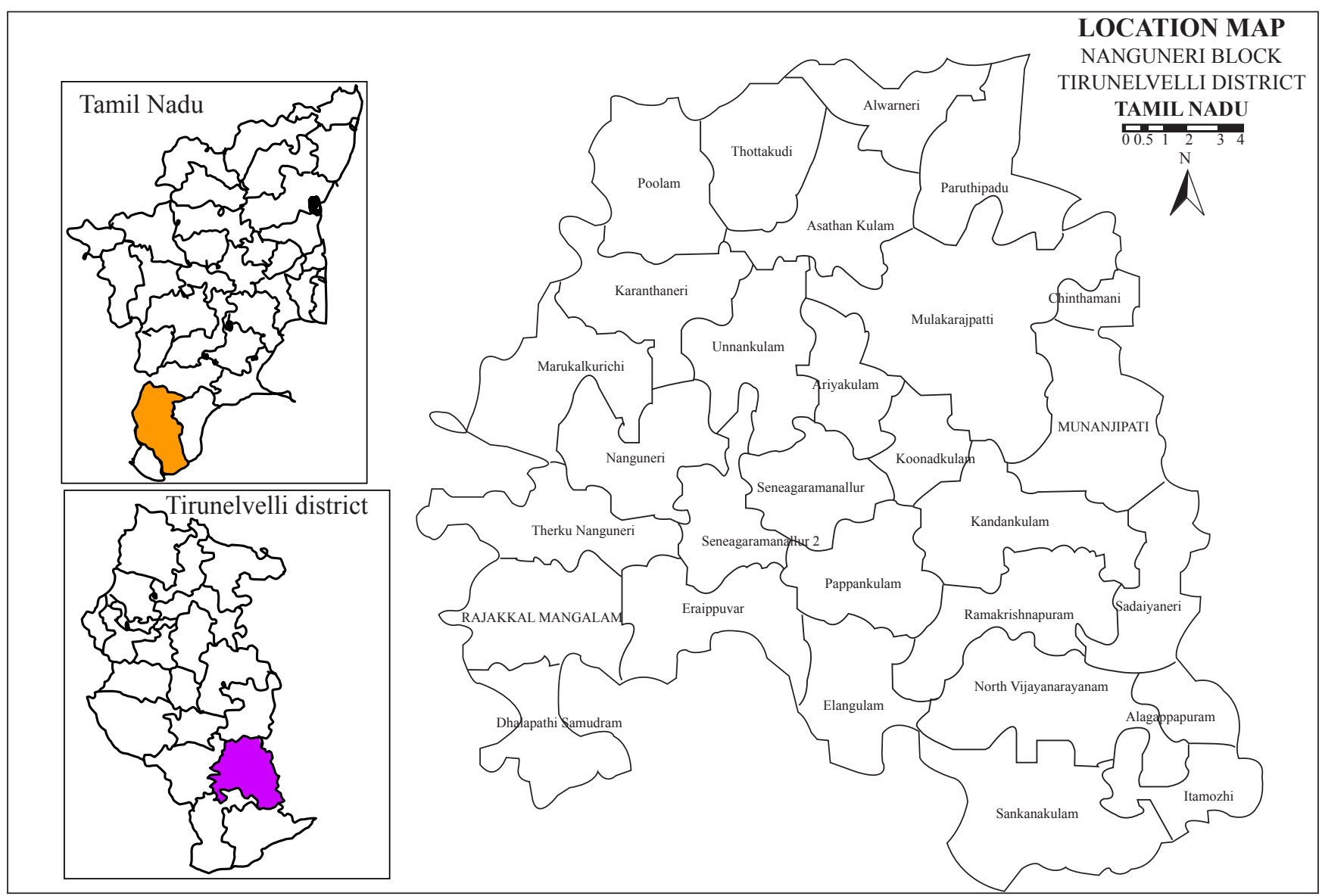

Figure 1: Location map of Nanguneri block

Table 4: Rainfall, temperature and potential Evapotranspiration of Nanguneri block

\begin{tabular}{|c|c|c|c|c|c|}
\hline \multirow[t]{3}{*}{ Months } & & \multicolumn{4}{|c|}{ Nanguneri block } \\
\hline & & \multicolumn{2}{|c|}{$\begin{array}{c}\text { Mean } \\
\text { temperature }\end{array}$} & \multirow[t]{2}{*}{ PET } & \multirow[t]{2}{*}{$\begin{array}{l}\text { Rain- } \\
\text { fall }\end{array}$} \\
\hline & & max. & $\min$. & & \\
\hline January & \multirow{2}{*}{ winter } & 32.0 & 18.7 & 112.2 & 19.6 \\
\hline February & & 34.3 & 19.8 & 137.5 & 26.2 \\
\hline March & \multirow{4}{*}{ summer } & 36.5 & 22.0 & 167.0 & 28.2 \\
\hline April & & 37.7 & 23.5 & 171.4 & 44.5 \\
\hline May & & 38.3 & 24.8 & 183.5 & 28.8 \\
\hline June & & 37.2 & 25.7 & 173.0 & 18.1 \\
\hline July & \multirow{3}{*}{$\begin{array}{c}{ }^{*} \mathrm{SW} \\
\text { monsoon }\end{array}$} & 37.1 & 24.6 & 171.8 & 16.7 \\
\hline August & & 37.1 & 24.4 & 176.4 & 14.4 \\
\hline September & & 36.5 & 23.7 & 169.7 & 31.6 \\
\hline October & \multirow{4}{*}{$\begin{array}{l}\text { "NE } \\
\text { monsoon }\end{array}$} & 34.1 & 23.1 & 167.0 & 164.4 \\
\hline November & & 31.6 & 22.4 & 138.1 & 180.3 \\
\hline December & & 31.0 & 20.4 & 112.2 & 96.5 \\
\hline Mean annual & & 35.30 & 22.70 & 1879.8 & 669.4 \\
\hline
\end{tabular}

${ }^{*}$ SW: South West; "NE: North East and Soil $\mathrm{N}_{2}$ are affected by very severe to severe erosion and soil $\mathrm{N}_{3}$ and $\mathrm{N}_{4}$ are undergoing moderate erosion. The severe sheet erosion in the uplands and summits is major cause for shallow soil depth (Natarajan et al., 2010). Soil $\mathrm{N}_{4}$ and Soil $\mathrm{N}_{5}$ are alkaline in reaction $(\mathrm{pH}>8)$ whereas other soils are slightly acidic in reaction ( $\mathrm{pH} 6.07-6.46)$. The organic carbon content varies from $0.19 \%$ to $0.95 \%$ in the surface and $0.1 \%$ to 0.62 $\%$ in the sub-surface. Soil $\mathrm{N}_{3}$ recorded lowest organic carbon content $(0.19 \%)$ and soil $\mathrm{N}_{5}$ recorded higher organic carbon content $(0.95 \%)$. Cation exchange capacity varied from 13.9 to $\left.15.9 \mathrm{c} \mathrm{mol}^{(\mathrm{p}+}\right) \mathrm{kg}^{-1}$ in the surface and 8.1 to $10.5 \mathrm{c} \mathrm{mol}\left(\mathrm{p}^{+}\right) \mathrm{kg}^{-1}$ in the sub-surface. Available nitrogen content is very low $(99.7$ to $265 \mathrm{~kg} \mathrm{ha}^{-1}$ ). Available Phosphorous and potassium content ranged from $6.4-28.5$ and $103.7-559 \mathrm{~kg} \mathrm{ha}^{-1}$ respectively.

\subsection{Land Suitability evaluation}

The study area is under water scarce, land use system should emphasize on cultivation of low water requirement and high value medicinal plants (Kiran et al., 2009; Pirbalouti et al., 2011; Nimasow et al., 2016). The soil morphological and physiochemical parameters obtained from field as well as laboratory along with climate were evaluated for suitability of Aswagandha, Senna and Tulsi. Climatic parameters such as 


\begin{tabular}{|c|c|c|c|c|c|c|}
\hline \multicolumn{2}{|l|}{ Soil } & $\mathrm{N}_{1}$ & $\mathrm{~N}_{2}$ & $\mathrm{~N}_{3}$ & $\mathrm{~N}_{4}$ & $\mathrm{~N}_{5}$ \\
\hline \multicolumn{7}{|c|}{ Site characteristics } \\
\hline \multicolumn{2}{|c|}{ Slope (\%) } & $1-3$ & $1-3$ & $0-1$ & $0-1$ & $0-1$ \\
\hline \multicolumn{2}{|l|}{ Drainage } & Well & Mod. Well & Well & Well & Mod. Well \\
\hline \multicolumn{2}{|l|}{ Flooding } & F0 & F0 & F0 & F0 & F0 \\
\hline \multicolumn{2}{|l|}{ Erosion } & Very severe & severe & moderate & moderate & slight \\
\hline \multicolumn{7}{|c|}{ Soil characteristics } \\
\hline \multicolumn{2}{|l|}{ Texture } & $\mathrm{scl}$ & $\mathrm{gc}$ & gsc & $\mathrm{sc}$ & $\mathrm{sc}$ \\
\hline \multicolumn{2}{|l|}{ Depth (cm) } & 25 & 52 & 70 & 90 & 130 \\
\hline \multicolumn{2}{|l|}{ Gravels (\%) } & 50 & 40 & 40 & 25 & - \\
\hline \multicolumn{2}{|c|}{ Effervescence with acid } & $\mathrm{e} 0$ & $\mathrm{e} 0$ & $\mathrm{e} 0$ & $\mathrm{e} 0$ & $\mathrm{e} 0$ \\
\hline \multicolumn{7}{|c|}{ Physiochemical characteristics } \\
\hline \multirow[t]{2}{*}{$\mathrm{pH}$} & surface & 6.46 & 6.38 & 6.07 & 8.18 & 8.68 \\
\hline & subsurface & 6.6 & 6.48 & 5.9 & 8.14 & 8.62 \\
\hline \multirow[t]{2}{*}{$\mathrm{EC} \mathrm{dSm}^{-1}$} & surface & 0.11 & 0.14 & 0.06 & 0.10 & 0.15 \\
\hline & subsurface & 0.05 & 0.15 & 0.03 & 0.27 & 0.16 \\
\hline \multirow[t]{2}{*}{ OC $(\%)$} & surface & 0.47 & 0.59 & 0.19 & 0.67 & 0.95 \\
\hline & subsurface & 0.35 & 0.62 & 0.35 & 0.1 & 0.23 \\
\hline \multirow{2}{*}{$\begin{array}{l}\text { CEC } \\
\text { C mol }\left(\mathrm{p}^{+}\right) \mathrm{kg}^{-1}\end{array}$} & surface & 14.8 & 15.4 & 13.9 & 15.7 & 15.9 \\
\hline & subsurface & 9.6 & 10.5 & 8.1 & 9.4 & 10 \\
\hline \multicolumn{2}{|c|}{ Available $\mathrm{N}\left(\mathrm{kg} \mathrm{ha}^{-1}\right)$} & 232 & 265 & 132.9 & 99.7 & 132.9 \\
\hline \multicolumn{2}{|c|}{ Available P $\left(\mathrm{kg} \mathrm{ha}^{-1}\right)$} & 7.3 & 28.5 & 14.6 & 6.4 & 17.93 \\
\hline \multicolumn{2}{|c|}{ Available K $\left(\mathrm{kg} \mathrm{ha}^{-1}\right)$} & 353 & 175.8 & 103.7 & 147 & 559 \\
\hline \multicolumn{2}{|c|}{ DTPA Fe $\left(\mathrm{mg} \mathrm{kg}^{-1}\right)$} & 7.02 & 4 & 3.28 & 14.62 & 10.52 \\
\hline \multicolumn{2}{|c|}{ DTPA Mn $\left(\mathrm{mg} \mathrm{kg}^{-1}\right)$} & 6.16 & 9.98 & 4.9 & 8.98 & 6.92 \\
\hline \multicolumn{2}{|c|}{ DTPA Cu $\left(\mathrm{mg} \mathrm{kg}^{-1}\right)$} & 1.04 & 2.66 & 4.3 & 2.04 & 3.86 \\
\hline \multicolumn{2}{|c|}{ DTPA Zn $\left(\mathrm{mg} \mathrm{kg}^{-1}\right)$} & 0.18 & 0.1 & 0.16 & 0.2 & 0.14 \\
\hline
\end{tabular}

Mod. Well: Moderately well drained; F0: No flooding; scl: Sandy clay loam; gc: Gravelly clay; gsc-Gravelly sandy clay; sc: sandy clay; e0: Nil effervescence with dil Hcl

rainfall, temperature and length of growing period are highly suitable for all the medicinal plants. The major limiting factor in the study area is depth and texture. Though cation exchange capacity and organic carbon is limiting factor in the soils, these can overcome by applying site specific recommendations. The non parametric approach revealed the Soils $\mathrm{N}_{4}$ and $\mathrm{N}_{5}$ are highly suitable for cultivation of Aswagandha whereas $\mathrm{N}_{2}$ and $\mathrm{N}_{3}$ are moderately suitable with the limitations of texture and $\mathrm{pH}$. Soil $\mathrm{N}_{3}$ is marginally suitable for Senna due to limitations of texture and drainage whereas as $\mathrm{N}_{2}, \mathrm{~N}_{4}$ and $\mathrm{N}_{5}$ soils are highly suitable for cultivation. Soil $\mathrm{N}_{2}, \mathrm{~N}_{4}$ and $\mathrm{N}_{5}$ are highly suitable for cultivation of Tulsi. Soil $\mathrm{N}_{1}$ is not suitable for all the three medicinal plants due to shallow depth. The area analysis revealed that 11051 ha $(53.4 \%)$ of fallow lands in Nanguneri block is highly suitable for Aswagandha cultivation and $14913(72.2 \%)$ ha is highly suitable for Senna and Tulsi whereas 1819 ha (8.7\%) of fallow lands is not suitable for all the three medicinal plants.

\section{Conclusion}

The primary objective of this study is to predict the inherent suitability of fallow lands for supporting different medicinal plants for a long period of time. Fallow lands resources were characterized to evaluate the suitability of soils for three medicinal plants Aswagandha, Senna and Tulsi. The results showed that $53.4 \%$ of fallow lands in Nanguneri block is highly suitable for Aswagandha $72.2 \%$ of fallow lands is highly suitable for Senna and Tulsi cultivation. This study helps to convert the unproductive lands into productive hub for medicinal plants. 
Table 6: Agro ecological and pedological related limitation and suitability for the cultivation of medicinal plants in Nanguneri fallow lands

\begin{tabular}{|c|c|c|c|c|c|c|c|c|c|c|c|c|c|c|c|}
\hline \multirow[t]{2}{*}{ Soil } & \multicolumn{3}{|c|}{$\mathrm{N}-1$} & \multicolumn{3}{|c|}{$\mathrm{N}-2$} & \multicolumn{3}{|c|}{$\mathrm{N}-3$} & \multicolumn{3}{|c|}{$\mathrm{N}-4$} & \multicolumn{3}{|c|}{$\mathrm{N}-5$} \\
\hline & A & $\mathrm{S}$ & $\mathrm{T}$ & A & $\mathrm{S}$ & $\mathrm{T}$ & A & $\mathrm{S}$ & $\mathrm{T}$ & A & $\mathrm{S}$ & $\mathrm{T}$ & A & $\mathrm{S}$ & $\mathrm{T}$ \\
\hline \multicolumn{16}{|l|}{ Climatic characteristics } \\
\hline Total annual rainfall (mm) & $\mathrm{S}_{1}$ & $\mathrm{~S}_{1}$ & $\mathrm{~S}_{1}$ & $\mathrm{~S}_{1}$ & $\mathrm{~S}_{1}$ & $\mathrm{~S}_{1}$ & $\mathrm{~S}_{1}$ & $\mathrm{~S}_{1}$ & $\mathrm{~S}_{1}$ & $\mathrm{~S}_{1}$ & $\mathrm{~S}_{1}$ & $\mathrm{~S}_{1}$ & $\mathrm{~S}_{1}$ & $\mathrm{~S}_{1}$ & $\mathrm{~S}_{1}$ \\
\hline Mean annual temperature $\left({ }^{\circ} \mathrm{C}\right)$ & $\mathrm{S}_{1}$ & $\mathrm{~S}_{1}$ & $\mathrm{~S}_{1}$ & $\mathrm{~S}_{1}$ & $\mathrm{~S}_{1}$ & $\mathrm{~S}_{1}$ & $\mathrm{~S}_{1}$ & $\mathrm{~S}_{1}$ & $\mathrm{~S}_{1}$ & $\mathrm{~S}_{1}$ & $\mathrm{~S}_{1}$ & $\mathrm{~S}_{1}$ & $\mathrm{~S}_{1}$ & $\mathrm{~S}_{1}$ & $\mathrm{~S}_{1}$ \\
\hline \multicolumn{16}{|l|}{ Site characteristics } \\
\hline Slope (\%) & $\mathrm{S}_{1}$ & $\mathrm{~S}_{1}$ & $\mathrm{~S}_{1}$ & $\mathrm{~S}_{1}$ & $\mathrm{~S}_{1}$ & $\mathrm{~S}_{1}$ & $\mathrm{~S}_{1}$ & $\mathrm{~S}_{1}$ & $\mathrm{~S}_{1}$ & $\mathrm{~S}_{1}$ & $\mathrm{~S}_{1}$ & $\mathrm{~S}_{1}$ & $\mathrm{~S}_{1}$ & $\mathrm{~S}_{1}$ & $\mathrm{~S}_{1}$ \\
\hline Drainage & $\mathrm{S}_{1}$ & $\mathrm{~S}_{1}$ & $\mathrm{~S}_{1}$ & $\mathrm{~S}_{1}$ & $\mathrm{~S}_{1}$ & $\mathrm{~S}_{1}$ & $\mathrm{~S}_{2}$ & $\mathrm{~S}_{2}$ & $\mathrm{~S}_{2}$ & $\mathrm{~S}_{1}$ & $\mathrm{~S}_{1}$ & $\mathrm{~S}_{1}$ & $\mathrm{~S}_{1}$ & $\mathrm{~S}_{1}$ & $\mathrm{~S}_{1}$ \\
\hline Flooding & $\mathrm{S}_{1}$ & $\mathrm{~S}_{1}$ & $\mathrm{~S}_{1}$ & $\mathrm{~S}_{1}$ & $\mathrm{~S}_{1}$ & $\mathrm{~S}_{1}$ & $\mathrm{~S}_{1}$ & $\mathrm{~S}_{1}$ & $\mathrm{~S}_{1}$ & $\mathrm{~S}_{1}$ & $\mathrm{~S}_{1}$ & $\mathrm{~S}_{1}$ & $\mathrm{~S}_{1}$ & $\mathrm{~S}_{1}$ & $\mathrm{~S}_{1}$ \\
\hline \multicolumn{16}{|l|}{ Soil characteristics } \\
\hline Texture & $\mathrm{S}_{1}$ & $\mathrm{~S}_{1}$ & $\mathrm{~S}_{1}$ & $\mathrm{~S}_{1}$ & $\mathrm{~S}_{1}$ & $\mathrm{~S}_{1}$ & $\mathrm{~S}_{2}$ & $\mathrm{~S}_{3}$ & $\mathrm{~S}_{3}$ & $\mathrm{~S}_{1}$ & $\mathrm{~S}_{1}$ & $\mathrm{~S}_{1}$ & $\mathrm{~S}_{1}$ & $\mathrm{~S}_{1}$ & $\mathrm{~S}_{1}$ \\
\hline Depth (cm) & $\mathrm{N}$ & $\mathrm{N}$ & $\mathrm{N}$ & $\mathrm{S}_{1}$ & $\mathrm{~S}_{1}$ & $\mathrm{~S}_{1}$ & $\mathrm{~S}_{1}$ & $\mathrm{~S}_{1}$ & $\mathrm{~S}_{1}$ & $\mathrm{~S}_{1}$ & $\mathrm{~S}_{1}$ & $\mathrm{~S}_{1}$ & $\mathrm{~S}_{1}$ & $\mathrm{~S}_{1}$ & $\mathrm{~S}_{1}$ \\
\hline \multicolumn{16}{|l|}{ Soil fertility } \\
\hline $\mathrm{EC}\left(\mathrm{dSm}^{-1}\right)$ & $\mathrm{S}_{1}$ & $\mathrm{~S}_{1}$ & $\mathrm{~S}_{1}$ & $\mathrm{~S}_{1}$ & $\mathrm{~S}_{1}$ & $\mathrm{~S}_{1}$ & $\mathrm{~S}_{1}$ & $\mathrm{~S}_{1}$ & $\mathrm{~S}_{1}$ & $\mathrm{~S}_{1}$ & $\mathrm{~S}_{1}$ & $\mathrm{~S}_{1}$ & $\mathrm{~S}_{1}$ & $\mathrm{~S}_{1}$ & $\mathrm{~S}_{1}$ \\
\hline $\mathrm{pH}(1: 2.5)$ & $\mathrm{S}_{2}$ & $\mathrm{~S}_{1}$ & $\mathrm{~S}_{1}$ & $\mathrm{~S}_{2}$ & $\mathrm{~S}_{1}$ & $\mathrm{~S}_{1}$ & $\mathrm{~S}_{2}$ & $\mathrm{~S}_{2}$ & $\mathrm{~S}_{2}$ & $\mathrm{~S}_{2}$ & $\mathrm{~S}_{1}$ & $\mathrm{~S}_{1}$ & $\mathrm{~S}_{2}$ & $\mathrm{~S}_{2}$ & $\mathrm{~S}_{1}$ \\
\hline $\mathrm{CaCO}_{3}$ in root zone & $\mathrm{S}_{1}$ & $\mathrm{~S}_{1}$ & $\mathrm{~S}_{1}$ & $\mathrm{~S}_{1}$ & $\mathrm{~S}_{1}$ & $\mathrm{~S}_{1}$ & $\mathrm{~S}_{1}$ & $\mathrm{~S}_{1}$ & $\mathrm{~S}_{1}$ & $\mathrm{~S}_{1}$ & $\mathrm{~S}_{1}$ & $\mathrm{~S}_{1}$ & $\mathrm{~S}_{1}$ & $\mathrm{~S}_{1}$ & $\mathrm{~S}_{1}$ \\
\hline Suitability class for dominant soil & $\mathrm{N}$ & $\mathrm{N}$ & $\mathrm{N}$ & $\mathrm{S}_{2}$ & $S_{1}$ & $\mathrm{~S}_{1}$ & $\mathrm{~S}_{2}$ & $\mathrm{~S}_{3}$ & $\mathrm{~S}_{3}$ & $\mathrm{~S}_{1}$ & $\mathrm{~S}_{1}$ & $\mathrm{~S}_{1}$ & $\mathrm{~S}_{1}$ & $\mathrm{~S}_{1}$ & $\mathrm{~S}_{1}$ \\
\hline
\end{tabular}

$\mathrm{S}_{1}$ : Highly suitable; $\mathrm{S}_{2}$ : Moderately suitable; $\mathrm{S}_{3}$ : Marginally suitable; N: Non suitable; A: Aswagandha; $\mathrm{S}$ : Senna; T: Tulsi

\section{Acknowledgement}

We thank the Tamil Nadu State Planning Commission for sponsoring the project under Tamil Nadu State Land Use Research Board.

\section{References}

Cohen, M.M., 2014. Tulsi-Ocimum sanctum: A herb for all reasons. Journal of Ayurveda and Integrative Medicine 5(4), 251-259. http://doi.org/10.4103/09759476.146554

DES (Department of Economics and Statistics, Government of India), 2013. http://eands.dacnet.nic.in (accessed April, 2015)

Dharumarajan, S., Singh, S.K., 2014. GIS based soil site suitability analysis for potato - A case study in lower Indo-gangetic alluvial plain. Potato Journal 41, 113-121.

FAO, 1983. Food, and Agricultural Organization of the United Nations. Guidelines: Land evaluation for rainfed agriculture. FAO Soils Bulletin 52, FAO, Rome.

FSI, 2011. India State of Forest Report 2011. Forest Survey of India, Dehradun, India.

GOI, 2000. Report of the Taskforce on Medicinal Plants in India. Planning Commission, Government of India, Yojana Bhawan, New Delhi, India

Jackson, M.L., 1973. Soil Chemical Analysis. Prentice Hall of India Pvt. Ltd. New Delhi.
Jat, R.S., Nagaraja Reddy, R., Ruchi Bansal, Manivel, P., 2015. Good Agricultural Practices for Ashwagandha. Extension Bulletin. ICAR-Directorate of Medicinal and Aromatic Plants Research Boriavi, Anand-387 310, Gujarat.

Kayina, A., Reddy, G.S.N., 2012. Effect of organic manures, biofertilizers and inorganic fertilizers on growth and yield of Senna (Cassia angustifolia vahl.). Life sciences leaflets $6,35-41$.

Khanna, P.K., Kumar, A., Ahuja, A., Kishen Kaul, M., 2006. Biochemical composition of roots of Withania somnifera (L.) Dunal. Asian Journal of plant sciences 5, 1061-1063.

Kiran, N.R.A.P., Kudesia, R., Rani, M., Pal, A., 2009. Reclaiming Degraded Land in India Through the Cultivation of Medicinal Plants. Botany Research International 2 (3), 174-181

Kulkarni, S.K., Dhir, A., 2008. Withania somnifera: An Indian ginseng. Progress Neuro-Psychopharmacool. Biological Psychiatry 32(5), 1093-1105.

Lindsay, W.L., Norvell, W.A., 1978. Development of a DTPA soil test for zinc, iron, manganese, and copper.

Soil Science Society America Journal 42, 421-428

Naidu, L.G.K., Ramamurthy, V., Chella, O., Hegde, R., Krishnan, P., 2006. Manual for soil site suitability criteria for major crops. NBSS Publication 129, NBSS\&LUP, Nagpur, 118. 
Natarajan, A., Janakiraman, M., Manoharan, S., Anil Kumar, K.S., Vadivelu, S., Sarkar, D., 2010. Assessment of land degradation and its impacts on land resources of Sivagangai block, Tamil Nadu, India. In: Zdruli, P., Pagliai, M., Kapur, S., Cano, A.F. (Eds.), Land Degradation and Desertification: Assessment, Mitigation and Remediation DOI. 10.1007/978-90-4818657-0_18. Springer, Netherlands, 235-252.

Natarajan, A., Sarkar Dipak, 2010. Field guide for soil survey. NBSS\&LUP (ICAR), Nagpur, 73.

Natarajan, A., Reddy, P.S.A., Sehgal, J., Velayutham, M., 1997. Soil Resources of Tamil Nadu for Land Use Planning, NBSS Publication 46, 1-68.

Nimasow, G., Nimasow, O.D., Rawat, J.S., 2016. Remote sensing and GIS-based suitability modeling of medicinal plant (Taxus baccata Linn.) in Tawang district, Arunachal Pradesh, India. Current Science 110, 219-227.

Olsen, S.R., Cole, C.V., Watanabe, F.S., Dean, L.A., 1954. Estimation of Available Phosphorus in Soils by Extraction with Sodium Bicarbonate. U.S. Department of Agriculture 939.

Pirbalouti, A.G., 2009. GIS-based land suitability evaluation for rapeseed oil crop. Journal of Food, Agriculture and Environment 7, 837-840.

Pirbalouti, A.G., Bahrami, M., Reza Golpa Rvar, A., Abdollahi, K., 2011. GIS based land suitability assessment for German chamomile production. Bulgarian journal of Agricultural science 17, 93-98

Rajendran, K., Balaji, P., Jothi Basu, M., 2008. Medicinal plants and their utilization by villagers in southern districts of Tamil Nadu. Indian Journal of Traditional Knowledge 7(3), 417-420.
Ramamurthy, V., Singh, S.K., 2015. Land use Planning for important medicinal and aromatic plants in Karnataka. NBSS\&LUP publication 1081, Nagpur 22.

Ramasamy, C., Balasubramanaian, R., Sivakumar, S.D., 2005. Land use patterns with special reference to fallow lands- An Empirical investigation in Tamil Nadu. Indian Journal of Agricultural Economics 60, 629-643.

Season and crop report of Tamil Nadu, 2011. Department of Economics and Statistics, Chennai-600 006.

Shah, S., Saravanan, R., Gajbhiye, N.A., 2010. Phytochemical and physiological changes in Ashwagandha (Withania somnifera Dunal) under soil moisture stress. Brazilian Journal of Plant Physiology 22(4), 255-261. https:// dx.doi.org/10.1590/S1677-04202010000400005.

Sharma, V.P., 2011. India's Agricultural Development under the New Economic Regime: Policy Perspective and Strategy for the $12^{\text {th }}$ Five Year Plan.W.P. No. 2011-1101. Indian Institute of Management, Ahmedabad-380 015 , India.

Soil Survey Staff, 1993. Soil Survey Manual, Agriculture Handbook 18, USDA, Washington, DC.

Subbiah, B.V., Asija, G.L., 1956. A rapid procedure for estimation of available $\mathrm{N}$ in soils. Current Science 25, 149-153.

Sys, C., Van Ranst, E., Debaveye, J., 1991. Land evaluation, Part l, principles in land evaluation and crop production calculations. International Training Centre for Postgraduate Soil Scientists, University Ghent.

Walkley, A., Black, I.A., 1934. An estimation of the method for determining soil organic matter and a proposed modification of the chromic acid titration method. Soil science 37, 29-38. 